\title{
SEIZE THE MOMENT: The OpPortunity TO REALIZE THE HuMaN Right TO HEALTHCARE IN THE UNITED STATES
}

\author{
FRAN QUIGLEY*
}

I was privileged to be Eleanor Kinney's colleague. I was one of many who benefitted from her generous professional encouragement, and I learned much from both her word and her example. But one does not need to have known Eleanor personally to recognize the theme of her life's work. Her decades of distinguished teaching, service, and advocacy all point in a direction best illustrated by the sheer number of her articles and presentations that revolved around a single phrase: the human right to healthcare.

During Eleanor's career, her home country of the United States took significant steps in the direction of realizing that right, steps she helped push forward. The Children's Health Insurance Program (CHIP) was created in 1997 and expanded in 2009. Medicare's Part D prescription drug coverage passed in 2003. Plus, the Affordable Care Act was signed into law in 2010.

All have had an enormous impact. But they have not been enough to fulfill Eleanor's vision of a fully realized right to health in the United States. Even after the Affordable Care Act's implementation, 27 million U.S. residents are without insurance. ${ }^{1}$ Tens of millions more are underinsured. ${ }^{2}$ Even while many Americans suffer from deficient or absent care, the United States continues to spend more per capita on healthcare than any other nation. ${ }^{3}$

Yet, we may finally be on the cusp of change. "Medicare for All" proposals enjoy an unprecedented level of momentum. Well over half of Americans support a public healthcare system that would cover all people and all costs. ${ }^{4}$ They also

* Clinical professor at the Indiana University Robert H. McKinney School of Law, Director of the Health and Human Rights Clinic. Editor of the weekly publication, Faith in Healthcare, and coordinator of the non-profit advocacy group of the same name. Author of four books and dozens of mass media and academic articles focusing on access to healthcare as a human right. Portions of this essay have been published in different forms in the e-publication Faith in Healthcare. Plug the Hole, Part 2: The Problem with Watered-Down Versions of Medicare for All, FAITH IN HEALTHCARE, https://faithinhealthcare.org/fhc/plug-hole-part-2-problem-watered-down-versionsmedicare-all [https://perma.cc/K45Y-Y3GS].

1. Key Facts about the Uninsured Population, KAISER FAm. Found. (Dec. 7, 2018), https:/www.kff.org/uninsured/fact-sheet/key-facts-about-the-uninsured-population/ [https://perma.cc/M8KR-SD6V].

2. Natasha Bach, More Americans Have Health Care Coverage-But Millions Are Underinsured, ForTunE (Feb. 7, 2019), https://fortune.com/2019/02/07/americans-health-careunderinsured-rate/ [https://perma.cc/2ZAK-WE7E].

3. Karen Feldsher, What's Behind High U.S. Health Care Costs, HaRv. GazeTte (Mar. 13, 2018), https://news.harvard.edu/gazette/story/2018/03/u-s-pays-more-for-health-care-with-worsepopulation-health-outcomes/ [https://perma.cc/PYN2-GJBA].

4. Morning Consult \& Politico, National Tracking Poll \#190675, June 29 - July 012019 : Crosstabulation Results, MORNING CONSUlt 341 (2019), https://morningconsult.com/wpcontent/uploads/2019/07/190675_crosstabs_POLITICO_RVs_v2_BH.pdf[https://perma.cc/NP8X- 
support that public plan being a single-payer model, thus replacing private insurance companies, provided they can keep access to their preferred providers. That access is a hallmark of Medicare for All legislation that is sponsored by more than 100 members of the U.S. House of Representatives, ${ }^{5}$ more than a third of the Democrats in the U.S. Senate, and four leading candidates for the 2020 Presidential election. ${ }^{6}$

Let's seize this opportunity to realize Eleanor's vision. And let's not settle for any half-measures.

\section{FIXING THE HOLE IN OUR HEALTHCARE PIPELINE}

Despite a significant percentage of Republican voters supporting a Medicare for All program, nearly all of its legislative support comes from within the Democratic Party. Most predictions are that, for the reform to happen, the Democrats will first need to win control over the Presidency and Congress. But it may not be that simple.

Despite the populist demand for momentous change, there are proposals, even within the Democratic Party, that would retain the fundamental flaw of our current, broken system. Senator Joe Biden and several other Presidential candidates support a "public option," a government health plan that would serve as one choice among existing for-profit private plans. ${ }^{7}$ House Speaker Nancy Pelosi supports building on the Affordable Care Act by offering more generous subsidies for purchasing insurance, ${ }^{8}$ again from private corporations. And the Democrat-connected think tank Center for American Progress has advanced a proposal called Medicare Extra for All, promising automatic enrollment in health plans. ${ }^{9}$ The common thread running through all these proposals is that they retain a prime spot in our healthcare system for for-profit insurance corporations.

So, what's wrong with that? After all, the ultimate goal for healthcare reform - for Eleanor Kinney and for all of us who follow in her footsteps - is to ensure universal coverage, not to take down a particular industry. And passing

$747 \mathrm{Y}]$.

5. Medicare for All Act of 2019, H.R. 1384, 116th Cong. (2019).

6. Kevin Uhrmacher, Kevin Schaul \& Jeff Stein, Where 2020 Democrats Stand on Healthcare for All, WASH. POST, https://www.washingtonpost.com/graphics/politics/policy2020/medicare-for-all/ [https://perma.cc/ZM5R-FYE9].

7. Christina Zhao, 2020 Candidate Joe Biden Backs Medicare Public Option: 'You All Should Have a Choice', NEwsweEK (Apr. 29, 2019, 09:22 PM), https://www.newsweek.com/2020candidate-joe-biden-backs-medicare-all-policy-you-all-should-have-choice-1409332 [https://perma.cc/8RKT-PJ4A].

8. Bruce Japsen, Pelosi Wants More Americans Subsidized to Buy Obamacare, ForBES (Jan. 6, 2019, 9:20 AM), https:/www.forbes.com/sites/brucejapsen/2019/01/06/pelosi-wants-moreamericans-subsidized-to-buy-obamacare/\#6d7d69491d27 [https://perma.cc/DFW3-GLBU].

9. Medicare Extra for All, CTR. FOR AM. Progress (Feb. 22, 2018, 6:00 AM), https://www.americanprogress.org/issues/healthcare/reports/2018/02/22/447095/medicare-extrafor-all/ [https://perma.cc/9NK3-5CL8]. 
any of these proposals into law would undoubtedly be an easier lift politically than Medicare for All. The health insurance industry already spends tens of millions of dollars on lobbying, political campaign donations, ${ }^{10}$ and public relations. Inevitably, the industry will ramp up those efforts to resist a singlepayer system that represents an existential threat to its business model.

Yet the proposals from Biden, Pelosi et al. that keep a role for private health insurance are not mere political compromises. They leave undisturbed the fundamental flaw in the U.S. system, ${ }^{11}$ the prime reason for the tragic irony of us paying more for worse outcomes than other countries: we waste approximately $\$ 500$ billion each year in healthcare money spent not on care, ${ }^{12}$ but on private insurance corporations' executive pay, shareholder returns, and a massive bureaucracy devoted to contesting insurance claims and marketing.

The metaphor is an obvious one: other countries enjoy better, less expensive healthcare because they deposit their healthcare dollars into a pipeline that flows directly to patients. In the United States, we put a historically abundant supply of dollars into our pipeline at the front end. However, we have allowed a gaping hole to develop in the middle, diverting hundreds of billions in taxpayer dollars to the benefit of wealthy corporate shareholders and CEO's making as much as $\$ 83$ million per year. ${ }^{13}$ Too few dollars are trickling through to the end of the pipeline, where sick people in need of care are located. If we are going to overhaul our system to finally provide healthcare for all, we need to plug that hole.

In addition, most of the healthcare reform proposals that retain a role for private insurance corporations also preserve a profound injustice in our current broken system: the deductibles and copays that so often prevent insurance coverage from translating to actual healthcare. Four in ten working Americans have a high-deductible plan. ${ }^{14}$ This force them to pay thousands of dollars out of pocket before they get any benefit from the premiums taken from their paychecks

10. See Ctr. for Responsive Pol., Industry Profile: Insurance, OpenSeCRETS, https://www.opensecrets.org/federal-lobbying/industries/lobbyists? cycle=2019\&id=f09 [https://perma.cc/5458-GFKD]; See generally Ctr. for Responsive Pol., Insurance: Summary, OPENSECRETS, https://www.opensecrets.org/industries/indus.php?ind=f09 [https://perma.cc/6K52LK5Y].

11. See generally Feldsher, supra note 3.

12. Emily Gee \& Topher Spiro, Excess Administrative Costs Burden the U.S. Health Care System, CTR. FOR AM. Progress (Apr. 8, 2019, 1:00 PM), https://www.americanprogress. org/issues/healthcare/reports/2019/04/08/468302/excess-administrative-costs-burden-u-s-healthcare-system/ [https://perma.cc/CLY4-NAC2].

13. Evan Sweeney \& Mike Stankiewicz, Health insurance CEOs earned $\$ 342.6 M$ in 2017 , FierceHeAlthCARE (May 7, 2018, 9:30 AM), https://www.fiercehealthcare.com/payer/ceo-pay2017-342-million-unitedhealth-molina-cigna-aetna [https://perma.cc/F533-UMWU]

14. See Morgan Haefner, Payer Issues: CDC finds 43.2\% of Americans Have HighDeductible Health Plans: 4 Additional Stats, BeCKer's HealthCARe (Feb. 23, 2018), https://www.beckershospitalreview.com/payer-issues/cdc-finds-43-2-of-americans-have-highdeductible-health-plans-4-additional-stats.html [https://perma.cc/6LWK-TU4H]. 
each week. The average amount of those deductibles has increased by more than $300 \%$ in the past decade. ${ }^{15}$

That means that many who are insured are forced to go without care. ${ }^{16}$ They skip doctor visits, they don't fill prescriptions, ${ }^{17}$ they cut their pills in half. This is true for many Americans under the current Medicare system too, with almost $40 \%$ of Medicare enrollees reporting that they skip care each year because of cost. ${ }^{18}$ The Medicare for All legislation proposals in the U.S. House and Senate use the Medicare name, but they would eliminate co-pays and deductibles. Despite the evidence that patient cost-sharing is proven to reduce the care compliance of persons with chronic illnesses ${ }^{19}$ the public option and ACA expansion plans keep those barriers in place - setting those persons up for damaging and expensive health crises.

\section{TAXPAYER HEALTHCARE DOLLARS FUNDING CORPORATE PROFITS, POOR CARE}

Given the central role that corporate money plays in our U.S. political system, it will come as no surprise that the most fervent supporters of preserving the role of for-profit health insurance corporations are financially tied to . . . for-profit health insurance corporations. Virtually all of the Democratic Party supporters of the public option and ACA expansion receive substantial funding from those corporations. $^{20}$

While well-funded lawmakers and think tanks parrot the industry's talking points, the industry often takes the messaging into its own hands. ${ }^{21}$ Health

15. Premiums for Employer-Sponsored Family Health Coverage Rise 5\% to Average \$19,616; Single Premiums Rise 3\% to \$6,896, KAISER FAM. Found. (Oct. 3, 2019), https://www.kff.org/health-costs/press-release/employer-sponsored-family-coverage-premiumsrise-5-percent-in-2018/ [https://perma.cc/ZB7T-URTW].

16. Aimee Picche, Higher Health Insurance Deductibles a Sickening Trend for Americans, CBS NEws (June 13, 2019, 3:34 PM), https://www.cbsnews.com/news/high-health-insurancedeductibles-a-sickening-trend-thats-causing-financial-hardship/?fbclid=IwAR0 dLNEQs 11jcCjdeXzLwkX71JB86c7M31lUCfwcjnNbncrYI0kflt8qDt0 [https://perma.cc/AG45-2HVJ].

17. Id.

18. Darla Mercado, Why Nearly 4 in 10 People on Medicare Skip Their Doctor's Visits, CNBC (Sept. 26, 2018, 1:04 PM), https://www.cnbc.com/2018/09/26/why-nearly-4-in-10-peopleon-medicare-skip-their-doctors-visits.html [https://perma.cc/KF6W-C5Y7].

19. Aaron E. Carroll, People with Chronic Illness Fare Worse Under Cost-Sharing, NY Times (May 19, 2014), https://www.nytimes.com/2014/05/20/upshot/why-patients-with-chronicillnesses-should-pay-less.html [https://perma.cc/CWJ4-VWC5].

20. Michael Corcoran, Meet the Health Care Industry's Favorite Democrats, TRuThout (Oct. 31， 2018), https://ruthout.org/articles/meet-the-health-care-industrys-favorite-democrats/ [https://perma.cc/LZ32-947G].

21. See Jeff Stein, 'We've Done a Lot More Than You Would Think': How the HealthInsurance Industry is Working to Pull Democrats Away from Medicare-For-All, WASH. Post (Apr. 12, 2019), https:/www.washingtonpost.com/business/2019/04/12/weve-done-lot-more-than-you- 
insurance CEOs like Cigna's David Cordani, who has made as much as $\$ 49$ million in annual compensation, ${ }^{22}$ predictably oppose Medicare for All. Instead, Cordani and his colleagues enthusiastically support an expansion of the "publicprivate partnerships," arrangements that directly divert taxpayer healthcare dollars to their corporations. ${ }^{23}$

Those partnerships are already substantial. For-profit health insurance corporations received a total of \$307 billion in Medicaid dollars in 2018-a little more than half of all state and federal government spending in the program. ${ }^{24}$ The Affordable Care Act's incentives for states to expand Medicaid has caused the number of such arrangements to double in recent years. ${ }^{25}$

The basic "managed care" arrangement is that private corporations are paid a set fee from government dollars each month for every Medicaid patient enrolled in their plan. ${ }^{26}$ The inherent problem is the incentive for corporations to increase their profits by limiting the amount they spend on care. Savings are achieved by restricting patients to a closed network of providers and by denying claims for care reimbursement. Dr. Andrew Bindman, former director of the federal Agency for Healthcare Research and now a professor at the University of California-San Francisco, told Kaiser Health News in 2018 "[t]his system is ripe for profittaking, and there is virtually no penalty for performing badly." ${ }^{27}$

In that same report, Kaiser noted that, in California alone, insurance corporations made $\$ 5.4$ billion in profits from 2014 to $2016 .{ }^{28}$ Predictably, a substantial amount of data and reporting shows that some of these private profits came from cutting costs in ways that caused patient suffering. ${ }^{29}$ Across multiple

would-think-how-health-insurance-industry-is-working-pull-democrats-away-medicare-for-all/ [https://perma.cc/MSX5-AYPF].

22. Mara Lee, Cigna CEO Received \$49 Million in Compensation Last Year, HARTFORD COURANT (Mar. 21, 2016, 7:07 PM), https://www.courant.com/business/hc-cigna-ceo-pay20160321-story.html [https://perma.cc/R2WA-M346].

23. Paige Minemyer, AHIP19: Cigna's Cordani Says it's Time to Press Pause on 'MedicareFor-All' Talk-But Change is Necessary, FierceHealthCare (June 19, 2019, 5:49 PM), https://www.fiercehealthcare.com/payer/ahip19-cigna-s-cordani-says-it-s-time-to-press-pausemedicare-for-all-talk-but-change [https://perma.cc/6428-PGNC].

24. Bob Herman, Most Medicaid dollars go to Health Insurers, Axios (Apr. 19, 2019), https:/www.axios.com/medicaid-managed-care-spending-health-insurers-224b5068-bcfe-495aaef5-b90e9f1c4c10.html [https://perma.cc/6YK4-YEY3].

25. See Christine Vestal, Managed Care Explained: Why a Medicaid Innovation is Spreading, PEW TRusts (May 31, 2011), https://www.pewtrusts.org/en/research-and-analysis/ blogs/stateline/2011/05/31/managed-care-explained-why-a-medicaid-innovation-is-spreading [https://perma.cc/D8BA-VHRS].

26. Id.

27. Chad Terhune, Billions of Tax Dollars Flow to Private Medicaid Plans. But is Anyone Minding the Store?, L.A. TiMES (Oct. 18, 2018, 2:25 PM), https://www.latimes.com/business/la-fimedicaid-private-insurance-20181018-story.html [https://perma.cc/M9RF-HFHG].

28. $I d$.

29. See id. 
states that have outsourced their Medicaid duties to private corporations via the managed care model, lawmakers and patients complain about poorly managed and wrongfully denied care. ${ }^{30}$

For example, in Texas, young D'Ashon Morris was left permanently braindamaged when his Medicaid care was reduced to a dangerously low level. ${ }^{31}$ That fateful decision to reduce Morris's care saved money for the corporation that Texas pays to manage Medicaid, a common enough occurrence that it triggered an award-winning year-long investigation by the Dallas Morning News called "Pain and Profit." 32 Similar privatizing arrangements have caused an outcry in states like Iowa ${ }^{33}$ where reduced care has led to lawsuits and complaints by both patients and providers.

More broadly, recent research shows that Medicaid members in private corporation plans have more difficulty managing their asthma and blood pressure compared to their counterparts in public programs. ${ }^{34}$ Yet the Congressional Budget Office has concluded that pushing Medicaid care to private corporations has actually increased government spending. ${ }^{35}$

\section{THE FOR-PROFIT INCENTIVE TO DENY CARE}

The Medicaid managed care story is mirrored by the tale of Medicare Advantage plans, another process that diverts billions of public healthcare dollars to private corporations. Twenty million Americans on Medicare have chosen the private insurance option of Advantage plans, a number that represents a full onethird of Medicare enrollees. ${ }^{36}$ Many experts predict that, within a few years, half of all Americans on Medicare will be enrolled in an Advantage plan. ${ }^{37}$

30. Id.

31. J. David McSwane, Lawmakers Want Answers After Dallas Morning News Exposes Widespread Failure of Care, Dallas Morning News (June 19, 2018. 6:51 PM), https://www.dallasnews.com/news/2018/06/19/lawmakers-want-answers-after-dallas-morningnews-exposes-widespread-failure-of-care/ [https://perma.cc/G3T8-R9DK].

32. $I d$.

33. Simon Davis-Cohen, Iowa Privatized Medicaid: It has Been a Disaster. Here's Why., TARBELL (Apr. 25, 2019), https:/tarbell.org/2019/04/iowa-privatized-medicaid-it-has-been-adisaster-heres-why/?ref=featured\&link_id=2\&can_id=194470 cb866f434b7 bee $8 \mathrm{db} 26$ aacc172\&source=email-privatized-medicaid-is-failing-iowans-and-drug-distributors-feelthe-heat\&email_referrer=email_535719\&email_subject=privatized-medicaid-is-failing-iowansand-drug-distributors-feel-the-heat [https://perma.cc/8CM4-VPTV].

34. Managed Care's Effect on Outcomes, MediCAID AND CHIP PAYMENT AND ACCESS COMM'N, https:/www.macpac.gov/subtopic/managed-cares-effect-on-outcomes/ [https://perma.cc/ MD7J-GWEB].

35. Terhune, supra note 27.

36. Robert Pear, Medicare Advantage Plans Found to Improperly Deny Many Claims, N.Y. TiMES (Oct. 13, 2018), https://www.nytimes.com/2018/10/13/us/politics/medicare-claims-privateplans.html [https://perma.cc/U6D8-Q7E5].

37. $I d$. 
That enrollment is fueled by the aggressively advertised surface attractions of Advantage plans. The private plans set a limit on out-of-pocket medical expenses, which traditional Medicare does not. Furthermore, some Advantage plans offer added benefits like dental, vision, and drug coverage. ${ }^{38}$ But there is a catch: the corporations more than make up their costs of offering these benefits by cutting their expenses elsewhere. As with Medicaid managed care plans, they restrict enrollees to a limited network of providers, which means that going outof-network for care can trigger a huge cost to patients. ${ }^{39}$ That outcome can be difficult to avoid, as a Center for Medicare and Medicaid Services analysis showed that nearly half of all Advantage corporations' listings of networkincluded physicians contained errors. ${ }^{40}$ The Department of Justice in 2017 fined two Advantage plans \$32 million for misrepresenting the scope of their networks, among other misleading practices. ${ }^{41}$

For-profit Advantage corporations choose their network options with the goal of saving expenses and maximizing profit. And that can lead to compromised patient care. A Brown University study showed that Medicare Advantage enrollees are more likely to enter a lower-quality nursing home than someone enrolled in traditional Medicare. ${ }^{42}$ Those findings were included in a Kiplinger's Retirement Report analysis showing that Advantage plans can work well for seniors - as long as they don't need too much care. ${ }^{43}$ Judith Stein, executive director of the Center for Medicare Advocacy, told Kiplinger "[b]ut if they become ill or injured and really need a significant length of care, they are not as well-served." 44

That conclusion is consistent with a recent, disturbing report by the Inspector General of the U.S. Department of Health and Human Services. ${ }^{45}$ The Inspector

38. U.S. Centers for Medicare \& Medicaid Services, Medicare Advantage Plans cover all Medicare services, MEDICARE, https://www.medicare.gov/what-medicare-covers/what-medicarehealth-plans-cover/medicare-advantage-plans-cover-all-medicare-services [https://perma.cc/6V66WU8P].

39. Gretchen Jacobson, Matthew Rae, Tricia Neuman, Kendal Orgera \& Cristina Boccuti, KAISER FAM. FOUND. (Oct. 5, 2017), https:/www.kff.org/medicare/report/medicare-advantagehow-robust-are-plans-physician-networks/ [https://perma.cc/JM85-LFYR].

40. Lisa Ward, Beware Medicare Advantage Plans, WALl StReEt J. (Nov. 27, 2016, 10:11

PM), https://www.wsj.com/articles/beware-medicare-advantage-plans-1480302660 [https://perma.cc/P9HJ-9PA2].

41. Faegre Baker Daniels, An Unsettling Settlement: Health Plan to Pay \$32 Million to Settle Coding and Provider Network Misrepresentation Charge, JD SupRA (June 6, 2017), https://www.jdsupra.com/legalnews/an-unsettling-settlement-health-plan-to-57981/ [https://perma.cc/9WKK-AQGX].

42. Eleanor Laise, Medicare vs. Medicare Advantage: Ill Health Often Leads to Plan Switch, KIPLINGER (Apr. 11, 2018), https://www.kiplinger.com/article/retirement/T039-C000-S004medicare-vs-medicare-advantage-ill-health-switch.html [https://perma.cc/MN3N-ZR79].

43. Id.

44. Id.

45. Medicare Advantage Appeal Outcomes and Audit Findings Raise Concerns About Service 
General found "widespread and persistent problems" with improper denials of care and payment by Advantage programs. ${ }^{46}$ The report showed that three of every four appeals of Advantage program denials of care and payment led to reversals at the very first stage of review, a remarkably high error rate. ${ }^{47}$

Less remarkable was the Inspector General's conclusion about the root cause of so many wrongful denials of care and payment. As with Medicaid managed care programs, Medicare Advantage corporations are paid a set fee per patient, thus creating the motive to deny expensive claims. The Inspector General concluded,"[a] central concern about the (Advantage program) is the potential incentive for insurers to inappropriately deny access to services and payment in an attempt to increase their profits. ${ }^{~} 48$ The savings from wrongfully denied care may be fueling profits, but they are not reducing costs to the taxpayers that fund the programs. In fact, Medicare Advantage programs cost the government four percent more per person than traditional Medicare. ${ }^{49}$

\section{WhY NOT A PUBLIC OPTION?}

Most of us who have wrangled with our own health insurance companies are well aware of the problems inherent in a system that incentivizes the denial of care. Health insurance corporations reliably score near the bottom of consumer satisfaction surveys. ${ }^{50}$ How can that dismal corporate image be reconciled with the claims of some Democrats like Speaker Pelosi that "[a] lot of people love having their employer-based insurance" ? $^{51}$

It turns out that Pelosi et al. are misreading the views of the American public. When polling questions drill down a bit, they reveal that people want to retain access to their preferred healthcare providers, not necessarily their insurance company. ${ }^{52}$ Further, keeping access to providers is actually far more likely in a public Medicare for All system, which features free choice of providers, than in

and Payment Denials, OfF. OF InSPECTOR GeN. (Sept. 25, 2018) https://oig.hhs.gov/oei/reports/oei09-16-00410.asp [https://perma.cc/6E3G-AG2H].

46. $I d$.

47. $I d$.

48. Id.

49. Medicaid Payment Advisory Comm'n, Medicare Payment Policy: Report to CONGRESS 367 (Mar. 2017), http://medpac.gov/docs/default-source/reports/mar17_entirereport.pdf [https://perma.cc/CVR3-R2SM].

50. Axios, Polls: Americans Aren't Happy With Their Health Insurance - Are You?, CountaBle (Nov. 13, 2018), https://www.countable.us/articles/15093-polls-americans-aren-thappy-health-insurance [https://perma.cc/BB8M-QW9P].

51. Paul Kane \& Rachael Bade, 'I'm Agnostic': Pelosi Questions Whether Medicare-for-All Can Deliver Benefits of Obamacare, WASH. Post (Apr. 4, 2019, 8:21 PM), https://www. washingtonpost.com/politics/im-agnostic-pelosi-questions-whether-medicare-for-all-can-deliverbenefits-of-obamacare/2019/04/04/fe2942c0-56ed-11e9-aa83-504f086bf5d6_story.html [https://perma.cc/JWM5-DVNY].

52. Morning Consult \& Politico, supra note 4, at 357. 
a network-constrained system of employer-provided for-profit health insurance. In our current private insurance model, job turnover and employer-initiated plan switches mean that one of every four Americans switch their health insurance plans each year, ${ }^{53}$ and risk being barred from their preferred doctor or hospital as a result.

So why not embrace a public option plan? Surely, the clear benefits of the public health plan - with no deductibles, no incentive to deny claims, and broader access to providers - can compete favorably with private insurance. As Biden says, "[w]hether you're covered through your employer or on your own or not, you all should have a choice to be able to buy into a public option plan for Medicare ... . If the insurance company isn't doing the right thing by you, you should have another choice. 54

That choice would be a no-brainer - if the competition was a fair one. But it won't be. As is already the case with Medicare vs. Medicare Advantage, forprofit corporations will push the sicker and more expensive enrollees to the public program - thus socializing the risk of insurance while privatizing the profits.

Plus, those corporations will inevitably deploy their legions of lobbyists and millions in campaign dollars to push for government regulations and policies that benefit the for-profit options and undermine the public program. These procorporate practices are already being embraced by the Trump administration to benefit the Advantage programs in their competition with traditional Medicare. ${ }^{55}$ The unchecked corporate ability to game the U.S. regulatory system is a key difference between any U.S. public option or ACA expansion proposal and the systems in other nations that retain a role for private insurance corporations. Nations such as Germany do accommodate private insurance, but only in a carefully circumscribed role and with substantial involvement by non-profit companies, an approach far removed from any of the current U.S. proposals. ${ }^{56}$

\section{SEIZE THE OPPORTUNITY FOR MEANINGFUL REFORM}

Most fundamentally, keeping or even expanding the current practice of using taxpayer dollars to subsidize the profiteering of private corporations translates to a lost opportunity. Proposals that bypass Medicare for All to protect corporate CEO's and shareholders deny the rest of us the benefit of massive savings-wellrepresented by the shocking disparity between Medicare's overhead administrative costs of around $2 \%$ and private corporations' estimated overhead

53. Matt Bruenig, People Lose Their Employer-Sponsored Insurance Constantly, PeOPLE'S PoL'y Project (Apr. 4, 2019), https://www.peoplespolicyproject.org/2019/04/04/people-lose-theiremployer-sponsored-insurance-constantly/ [https://perma.cc/26YK-EA45].

54. Zhao, supra note 7.

55. Robert Pear, Trump Administration Peppers Inboxes with Plugs for Private Medicare Plans, N.Y. Times (Dec. 1, 2018), https:/www.nytimes.com/2018/12/01/us/politics/trumpmedicare-advantage-plans.html [https://perma.cc/MZ5Y-U56T].

56. Adam Gaffney, Single-Payer or Bust, Dissent (Spr. 2018), https://www.dissentmagazine. org/article/single-payer-or-bust-two-souls-universal-healthcare [https://perma.cc/RNF3-MDZS]. 
of $20 \% .^{57}$ As multiple economic analyses have demonstrated, the savings from plugging up the pipeline hole diverting healthcare dollars to for-profit waste can fund our expansion into the universal coverage. ${ }^{58}$

A final problem with preserving an option for for-profit insurance plans is that the universality of the Medicare for All system is critical to its survival as a new institution in the United States. The well-settled political reality in the United States and beyond is that universal benefit programs survive and even thrive, while limited-eligibility programs are at perpetual risk of reduction or even elimination. Social Security, Medicare, and public education have become the "third rail" of U.S. politics - elected officials touch them at their peril. Compare that to means-tested programs like the Supplemental Nutrition Assistance Program (SNAP, aka Food Stamps), the Temporary Assistance for Needy Families program, and Head Start. All produce remarkable benefits yet have been on the budgetary chopping block for decades. Medicare for All will avoid that fate, and derive its political strength, from its final two words --"for All."

Democratic Party leaders know all this. So, it's time for them to overcome their fear of a powerful industry. It is time for them to listen to Americans who are demanding a substantial and sustainable change. It is time for them to seize the moment, and finally fulfill Eleanor Kinney's lifelong quest to see healthcare become a realized human right.

57. Dean Baker, A Warning for the Washington Post's Fact Checker on Single Payer Costs, CTR. FOR ECON. \& POL'Y RES. (Sept. 19, 2017), http://cepr.net/blogs/beat-the-press/a-warning-forthe-washington-post-s-fact-checker-on-single-payer-costs [https://perma.cc/PFF7-VTD6].

58. New Study Does the Math: Yes, We Can Afford Medicare for All, Faith In HealthCare, https://faithinhealthcare.org/fhc/new-study-does-math-yes-we-can-afford\%C2\%A0medicare-all [https://perma.cc/TVZ3-3DMR]. 